Transportation Research Forum

An Ex-Ante Cost-Benefit Analysis of All-Terrain Vehicle Transportation Corridor in Southwest Alaska Author(s): Lee Elder and Andy Seidl

Source: Journal of the Transportation Research Forum, Vol. 44, No. 3 (Fall 2005), pp. 113-130

Published by: Transportation Research Forum

Stable URL: http://www.trforum.org/journal

The Transportation Research Forum, founded in 1958, is an independent, nonprofit organization of transportation professionals who conduct, use, and benefit from research. Its purpose is to provide an impartial meeting ground for carriers, shippers, government officials, consultants, university researchers, suppliers, and others seeking exchange of information and ideas related to both passenger and freight transportation. More information on the Transportation Research Forum can be found on the Web at www.trforum.org. 


\section{An Ex-Ante Cost-Benefit Analysis of All-Terrain Vehicle Transportation Corridor in Southwest Alaska}

This research explores the construction of a geotextile ATV corridor connecting two separate village subsets, Oscarville-Napakiak and Akiak-Akiachak, in the Kuskokwim River delta. Cost-benefit analysis was used to compare the costs of constructing a geotextile trail to the benefits derived from the reduction of injuries, fatalities, and fuel consumption observed on the existing river transportation corridor during a 20-year period. Secondary data was collected for population estimates, fatality and injury rates, while the rapid rural appraisal approach was used to access the traffic rates between each village subset. The results reveal that the construction of a geotextile ATV corridor in the Alaskan bush would prove to be an economically feasible transportation alternative.

\section{by Lee Elder and Andy Seidl}

\section{INTRODUCTION}

Communities in the Alaskan bush face infrastructure challenges that the general public in the continental United States have not experienced since the turn of the $20^{\text {th }}$ century. Although many of these bush communities currently have access to air transport, all terrain vehicle (ATV), ${ }^{1}$ and boat travel, the infrastructure is far from the level of quality, convenience, and safety many people in the United States enjoy.

The development of transportation corridors in the Alaskan bush has been hindered in part by the lack of a well-developed cash economy, the high cost of development, and the general inaccessibility of particular regions. Traditional "bricks and mortar" approaches to land-based transportation for cars and trucks are very likely to be inefficient solutions in a region where the human populations are low and dispersed and snow machines and four-wheelers are the preferred travel alternatives.

Currently there are approximately 6.97 million ATV users in the United States and this number is expected to grow by $32 \%$ to 9.28 million by 2010 (United States Environmental Protection Agency 2005). The boom of recreational ATV use in the United States calls into question whether or not trails can be constructed to provide land managers and government agencies an alternative to deal with trail degradation and safety improvements in their own particular locations.

This research estimates the benefits and costs (B-C) associated with the development of an ATV trail in rural southwestern Alaska from the perspective of the region's current and future residents. The ex ante $\mathrm{B}-\mathrm{C}$ analysis weighs the benefits from improved safety and decreases in fuel costs against the fixed and variable costs of trail construction. This accounting is evaluated relative to the riverine transportation corridor currently used by local residents. To our knowledge this is the first attempt to incorporate safety improvements in a B-C analysis for transportation in Alaska. Likewise, it is the first attempt to compare a riverine transportation corridor to a land route alternative in the region.

\section{Study Site}

Oscarville, Napakiak, Akiak, and Akiachak villages lie within the boundaries of the Yukon Delta National Wildlife Refuge (YDNWR) in southwestern Alaska. Napakiak lies approximately 15 miles southwest of Bethel, the regional commercial and population center, while Oscarville lies approximately six miles southwest of Bethel. Akiachak is 18 miles and Akiak 42 miles northeast of Bethel. The 2003 population of Napakiak was 380 people, while Oscarville had a population of 62 people. 
Akiachak had a population of 633, while Akiak was home to 337 people.

The areas near and around these villages are classified as either Kuskokwim flood plain or tundra uplands. Local soils are perennially frozen at shallow depths and permafrost is as thick as 450 feet in areas. The area is intersected with creeks and sloughs, and thaw lakes are common throughout the area (State of Alaska Department of Transportation 1981).

Local transportation is by boat in the warm months and by snow machine, cars, and trucks when ice thickness permits. The Kuskokwim River is either between breakup and freezeup for approximately two months per year. Therefore individuals are unable to continually travel by using the Kuskokwim River corridor safely (J. Weiss, pers. comm.).

Importantly from a B-C analysis perspective, the number of people in the region currently unemployed and not actively seeking work is extremely high. Napakiak has a jobless rate of $54.3 \%$ and unemployment in Oscarville is about $50 \%$ of the resident population. Akiak and Akiachak have a jobless population of $55.3 \%$ and $58.2 \%$, respectively (Alaska Department of Commerce Community and Economic Development 2005).

\section{LITERATURE REVIEW}

There have been many rural road improvement analyses performed, however, none have analyzed ATV trail development. Therefore, the contributing literature is focused on B$\mathrm{C}$ analyses of road projects. Below are some studies that provided some parameters and background for the current research.

Olsen (1986) evaluated 13 improvements on Alaska's Dalton Highway, a 28 foot wide gravel surfaced road, by exploring tangible benefits resulting from reduced operating costs. He explored options such as a 30 foot wide gravel road to that of paving the entire 416 miles of highway. Olsen (1986) concluded that no improvements were justifiable to the Dalton Highway unless traffic volume increased. Notably, he pointed out intangible benefits such as safety, environmental impacts, and development possibilities should be incorporated to provide a better understanding of the separate road improvements.

The current research is quite similar to research by Waters and Meyers (1987) where an ex ante B-C analysis was performed for the Coquihalla Highway in Canada. Waters and Meyers (1987) estimated benefits from fatality/injury, time, and operating costs reductions on the new highway alignment. A major discrepancy between the research in this paper and Waters and Meyers (1987) research is the methodology employed to determine traffic rates, which in their case, was based on surveys. Surveys were not ideal for the current research because of the likelihood of sampling bias as well as the cost effectiveness of doing so. This research uses Rapid Rural Appraisal (RRA) in the determination of traffic rates. RRA is a relatively quick way of gleaning data from a particular area by developing a rapport with the communities of interest (Chambers 1981). Therefore, the community leaders of each village were contacted by phone on more than one occasion and then provided a simple questionnaire to estimate what the current travel rates were between each village for boats, ATVs, and snowmachines.

Similarly, the research in this study and the Waters and Meyers (1987) research used fatality/injury rate reductions from the same literature. Waters and Meyers (1987) used previous research from Pacquette and Wright (1979) to arrive at a 33\% reduction in fatalities and injuries.

The evaluation of safety benefits for transportation alternatives requires the determination of statistical life and injury values. Boardman et al. (2001) provides an overview of the many different studies and research performed in statistical life and injury value estimates. Ultimately, Boardman et al. (2001) suggests that the most plausible range is between \$2.5 million and \$4.0 million in 1999 dollars. He based this assessment primarily on Miller's (1990) findings where 67 analyses are examined and re-evaluated using uniform values for travel time and discount rates to convert risk aversion estimates into values.

Waters and Meyers (1987) and Boardman et al. (1994) estimated the value of time saved 
for business travelers at the average gross wage for British Columbia hourly and salaried employees, whereas leisure travelers value their time at $25 \%$ of the same rate. The opportunity costs of labor in these villages are close to zero because of the high unemployment rates. Furthermore, these trips would more than likely be leisure trips and would be calculated by a small percentage of the average regional wage rate. For this reason, time in transit costs were excluded from the analysis.

\section{General Approach}

The likely benefits of the ATV trail include safety improvements and fuel savings, while the costs associated with trail construction include labor, capital and shipping. The probable size and direction of excluded impacts is discussed in the concluding remarks. The assumed project life is 20 years (2005-2024) and the discount rate is $7 \%$, reflecting a typical pretax return on private investments (Office of Management and Budget 2004). Sensitivity analyses are conducted to explore the robustness of the estimates to the variation within the relevant ranges of the focal variables.

\section{BENEFIT CALCULATION}

\section{Population}

Transportation demand is dependent upon the size of the population. Therefore, village population projections over the 2005-2024 period were established using the historic average growth rate (1.5\%) over the 1991-2003 period for the Bethel Census Area. Historical rates are assumed to be the best predictor of future population growth lacking specific additional information.

\section{Safety Improvements: Fatality and Injury Rates}

The ATV trail is expected to provide a safer travel alternative to river travel. As a result, injury and fatality reductions attributable to the ATV trail can be considered benefits of the proposed project. Typically, such benefits are calculated on the basis of accidents/fatalities per mile traveled. However, available fatality data from the Alaska Division of Public Health, Bureau of Vital Statistics (M. Mathew, pers. comm.) and injury data from the Alaska State Trauma Registry (M. Moore, pers. comm.) facilitated only the calculation of potential improvements in safety per capita rather than per mile traveled (Table 1). The most recent transportation fatality data are for 1994-2003, whereas the most recent data for transportation related injuries are for the years of 1991-2001.

There is little objective information from which an ex ante estimate of the degree of safety improvement attributable to the ATV trail relative to current riverine transport routes can be derived. As previously discussed, Boardman et al. (1994), used secondary data from the Canadian Ministry of Transportation for an ex post analysis of a transportation corridor. He found a 50\% reduction in fatalities and injuries occurred due to the improved road types. However, no research provides safety and fatality rates for a riverine transportation corridor. Lacking superior information, it is assumed that a $50 \%$ reduction in per capita transportation related injuries and fatalities would occur as a result of the project.

For our purposes, a conservative value of life, based on estimated wages lost, of $\$ 2.7$ million is assumed (Boardman et al. 2001). Using a simplistic approach proposed by Miller (1990) the value of \$2.7 million can be

Table 1: ATV, Snow Machine and Boating Facilities and Injuries/Rates

\begin{tabular}{|l|c|c|c|c|c|c|}
\hline & $\begin{array}{c}\text { Fatalities } \\
(1994 \text { 2003) }\end{array}$ & $\begin{array}{c}\text { Injuries } \\
(19912001)\end{array}$ & $\begin{array}{c}\text { Fatalities } \\
\text { Population } \\
(19942003)\end{array}$ & $\begin{array}{c}\text { Injury } \\
\text { Population } \\
(1991 \text { 2001) }\end{array}$ & Fatality Rate & Injury Rate \\
\hline Oscarville Napakiak & 1 & 8 & 4,121 & 4,368 & $0.0243 \%$ & $0.1832 \%$ \\
\hline A kiak A kiachak & 2 & 26 & 8,925 & 9,374 & $0.0224 \%$ & $0.2774 \%$ \\
\hline
\end{tabular}

Fatality and injury rates are expressed in terms of the percentage of the total community population over the course of the observation period that sustained fatalities and injuries. 
supported by assuming a working adult of 38 years of age values the remaining hours of life at the arbitrary wage rate of $\$ 15$. The remaining lifespan of an Alaskan Native American would be approximately 31 years and discounted by $2.5 \%$ the present value would be $\$ 2.9$ million, well within the range proposed by Boardman et al. (2001). ${ }^{2}$

Table 2 uses the annual costs of fatalities and injuries in Oscarville-Napakiak (O-N) as an example of how the present value of safety is determined for the ATV trail. Table 2 provides the calculations for fatality and injury costs provided in the first row of Table 3 . The annual fatality rates as were determined in Table 1 are multiplied by the statistical life value of $\$ 2.7$ million and then accordingly multiplied by the 2005 combined populations for Oscarville and Napakiak. This value is then discounted by $7 \%$ to arrive at the present value of fatalities and injuries for 2005. ${ }^{3}$ For O-N these values are presented in the last column of Table 2. The only difference between the first two rows of Table 2 is the $50 \%$ difference in fatality rates. Once the present values of fatalities and injuries for the with and without trails scenarios have been determined they are then subtracted from one another, as provided in the bottom two rows of Table 2, to provide the net present value of safety benefits from ATV trail development.

Table 3 contains the safety benefits for the years following 2005. Table 3 contains changes in population growth and discount factors for the 2005-2024 period (columns 2 and 3). The further into the future the value of fatalities and injuries are evaluated, the greater the effects of the discount factor. For example, the second row of Table 3 (2006) reveals a discount factor of .87 ; therefore, $87 \%$ of the actual value determined in 2006 is to be used because the future value of money is higher than the present value of money.

Row 2 of Table 3 also reveals a population of 462 and is the estimated future population in 2006 as the result of the application of the assumed $1.5 \%$ population growth rate. The computation of Table 3 uses the same formulas as provided in Table 2. The only dynamic variables from row to row in Table 3 are the population and discount factors. As indicated by the last two rows of Table 2, the present value of fatalities with trail construction is subtracted from the present value of fatalities without trails. These totals are summed over the

Table 2: Fatality and Injury Net Benefit Calculations

\begin{tabular}{|c|c|c|c|c|c|c|c|}
\hline 2005 & $\begin{array}{c}\text { O N } \\
\text { Annual } \\
\text { Fatality }\end{array}$ & $\begin{array}{l}\text { Statistical } \\
\text { Life Value }\end{array}$ & & Population & & $\begin{array}{l}\text { Discount } \\
\text { Factor }\end{array}$ & $\begin{array}{l}\text { Present } \\
\text { Value }\end{array}$ \\
\hline \multicolumn{8}{|l|}{ Fatality Calculations } \\
\hline Without Trail & 0.00024 & $\$ 2,737,534$ & $\mathrm{X}$ & 455 & $\mathrm{X}$ & 0.93 & $\$ 282,766$ \\
\hline \multirow[t]{2}{*}{$\begin{array}{l}\text { With Trail ( } 50 \% \text { reduction in } \\
\text { without trail rate) }\end{array}$} & $0.00012 x$ & $\$ 2,737,534$ & $x$ & 455 & $x$ & 0.93 & $\$ 141,383$ \\
\hline & $\begin{array}{c}\text { O N } \\
\text { A nnual } \\
\text { Injury Rate }\end{array}$ & $\begin{array}{l}\text { Statistical } \\
\text { Injury V alue }\end{array}$ & & Population & & $\begin{array}{l}\text { Discount } \\
\text { Factor }\end{array}$ & $\begin{array}{l}\text { Present } \\
\text { V alue }\end{array}$ \\
\hline \multicolumn{8}{|l|}{ Injury Calculations } \\
\hline Without Trail & $0.00183 \quad X$ & $\$ 61,540$ & $X$ & 455 & $X$ & 0.93 & $\$ 47,976$ \\
\hline $\begin{array}{l}\text { With Trail ( } 50 \% \text { reduction in } \\
\text { without trail rate) }\end{array}$ & $0.00092 x$ & $\$ 61,540$ & $X$ & 455 & $X$ & 0.93 & $\$ 23,988$ \\
\hline & $\begin{array}{c}\text { Present } \\
\text { Value w/o } \\
\text { ATV Trail }\end{array}$ & $\begin{array}{c}\text { Present } \\
\text { Value with } \\
\text { ATV Trail }\end{array}$ & & & & & $\begin{array}{l}\text { Net Present } \\
\quad \text { alue }\end{array}$ \\
\hline $\begin{array}{l}\text { Net Present } V \text { alue of } F \text { atality } \\
\text { Benefit }\end{array}$ & $\$ 282,766$ & $\$ 141,383$ & & & $=$ & & $\$ 141,383$ \\
\hline $\begin{array}{l}\text { Net Present } V \text { al ue of Injury } \\
\text { B enefit }\end{array}$ & $\$ 47,976$ & $\$ 23,988$ & & & $=$ & & $\$ 23,988$ \\
\hline
\end{tabular}

*computations may be slightly off due to rounding error 
20-year period to provide the total net present value of safety because of trail construction. In the case of Oscarville-Napakiak, the total present value of fatalities as a result of not constructing a trail is $\$ 3,588,188$ whereas injury costs are $\$ 608,791$ over the next 20 years. A $50 \%$ reduction in both fatality and injury rates creates a net benefit of $\$ 1,794,094$ and $\$ 304,396$, because of the construction of the ATV trail between Oscarville and Napakiak (Table 3).

As outlined previously, the estimated present value of fatalities between Akiak and Akiachak is determined by using the same methodology as for Oscarville-Napakiak. The formulas illustrated in Figure 1 were used to show that when the ATV trail is not constructed, the estimated present value of fatalities between Akiak-Akiachak is $\$ 7,270,902$, while the cost of injuries is $\$ 2,023,172$ (Table 4).

This difference is much greater than that of the cost associated with the $\mathrm{O}-\mathrm{N}$ trail because of the higher population in the Akiak-Akiachak (A-A) region. A 50\% reduction in the fatality and injury rates as the result of trail development generates a fatality cost of $\$ 3,635,451$ and an injury cost of $\$ 1,011,586$ and an analogous benefit of trail construction relative to the without-trail option.

Table 3: Fatality/Injury Cost and Resulting Benefit for Oscarville-Napakiak ATV Trail

\begin{tabular}{|r|r|r|r|r|r|r|r|r|}
\hline \multirow{2}{*}{ Y ear } & \multirow{2}{*}{$\begin{array}{c}\text { Discount } \\
\text { Factor }\end{array}$} & \multirow{2}{*}{ Population } & \multicolumn{2}{|c|}{ Without Trail } & \multicolumn{2}{c|}{ W ith Trail } & \multicolumn{2}{c|}{ Benefit } \\
\cline { 5 - 9 } & & & $\begin{array}{c}\text { Fatality } \\
\text { Value }\end{array}$ & $\begin{array}{c}\text { Injury } \\
\text { Value }\end{array}$ & $\begin{array}{c}\text { Fatality } \\
\text { Value }\end{array}$ & $\begin{array}{c}\text { Injury } \\
\text { Value }\end{array}$ & $\begin{array}{c}\text { Fatality } \\
\text { Value }\end{array}$ & $\begin{array}{c}\text { Injury } \\
\text { V alue }\end{array}$ \\
\hline 2005 & 0.93 & 455 & $\$ 282,766$ & $\$ 47,976$ & $\$ 141,383$ & $\$ 23,988$ & $\$ 141,383$ & $\$ 23,988$ \\
\hline 2006 & 0.87 & 462 & $\$ 268,248$ & $\$ 45,512$ & $\$ 134,124$ & $\$ 22,756$ & $\$ 134,124$ & $\$ 22,756$ \\
\hline 2007 & 0.82 & 469 & $\$ 254,476$ & $\$ 43,176$ & $\$ 127,238$ & $\$ 21,588$ & $\$ 127,238$ & $\$ 21,588$ \\
\hline 2008 & 0.76 & 476 & $\$ 241,411$ & $\$ 40,959$ & $\$ 120,705$ & $\$ 20,480$ & $\$ 120,705$ & $\$ 20,480$ \\
\hline 2009 & 0.71 & 483 & $\$ 229,016$ & $\$ 38,856$ & $\$ 114,508$ & $\$ 19,428$ & $\$ 114,508$ & $\$ 19,428$ \\
\hline 2010 & 0.67 & 491 & $\$ 217,258$ & $\$ 36,861$ & $\$ 108,629$ & $\$ 18,431$ & $\$ 108,629$ & $\$ 18,431$ \\
\hline 2011 & 0.62 & 498 & $\$ 206,104$ & $\$ 34,969$ & $\$ 103,052$ & $\$ 17,484$ & $\$ 103,052$ & $\$ 17,484$ \\
\hline 2012 & 0.58 & 506 & $\$ 195,522$ & $\$ 33,173$ & $\$ 97,761$ & $\$ 16,587$ & $\$ 97,761$ & $\$ 16,587$ \\
\hline 2013 & 0.54 & 513 & $\$ 185,484$ & $\$ 31,470$ & $\$ 92,742$ & $\$ 15,735$ & $\$ 92,742$ & $\$ 15,735$ \\
\hline 2014 & 0.51 & 521 & $\$ 175,961$ & $\$ 29,854$ & $\$ 87,980$ & $\$ 14,927$ & $\$ 87,980$ & $\$ 14,927$ \\
\hline 2015 & 0.48 & 529 & $\$ 166,927$ & $\$ 28,322$ & $\$ 83,463$ & $\$ 14,161$ & $\$ 83,463$ & $\$ 14,161$ \\
\hline 2016 & 0.44 & 537 & $\$ 158,356$ & $\$ 26,868$ & $\$ 79,178$ & $\$ 13,434$ & $\$ 79,178$ & $\$ 13,434$ \\
\hline 2017 & 0.41 & 545 & $\$ 150,226$ & $\$ 25,488$ & $\$ 75,113$ & $\$ 12,744$ & $\$ 75,113$ & $\$ 12,744$ \\
\hline 2018 & 0.39 & 553 & $\$ 142,513$ & $\$ 24,180$ & $\$ 71,257$ & $\$ 12,090$ & $\$ 71,257$ & $\$ 12,090$ \\
\hline 2019 & 0.36 & 561 & $\$ 135,196$ & $\$ 22,938$ & $\$ 67,598$ & $\$ 11,469$ & $\$ 67,598$ & $\$ 11,469$ \\
\hline 2020 & 0.34 & 570 & $\$ 128,255$ & $\$ 21,760$ & $\$ 64,128$ & $\$ 10,880$ & $\$ 64,128$ & $\$ 10,880$ \\
\hline 2021 & 0.32 & 579 & $\$ 121,670$ & $\$ 20,643$ & $\$ 60,835$ & $\$ 10,322$ & $\$ 60,835$ & $\$ 10,322$ \\
\hline 2022 & 0.30 & 587 & $\$ 115,424$ & $\$ 19,583$ & $\$ 57,712$ & $\$ 9,792$ & $\$ 57,712$ & $\$ 9,792$ \\
\hline 2023 & 0.28 & 596 & $\$ 109,498$ & $\$ 18,578$ & $\$ 54,749$ & $\$ 9,289$ & $\$ 54,749$ & $\$ 9,289$ \\
\hline 2024 & 0.26 & 605 & $\$ 103,876$ & $\$ 17,624$ & $\$ 51,938$ & $\$ 8,812$ & $\$ 51,938$ & $\$ 8,812$ \\
\hline Present V alue & & & $\$ 3,588,188$ & $\$ 608,791$ & $\$ 1,794,094$ & $\$ 304,396$ & $\$ 1,794,094$ & $\$ 304,396$ \\
\hline
\end{tabular}

*Population increases are estimated using the population growth (1.5\%) determined from the B ethel Census A rea over the 19912003 period. 
Table 4: Fatality/Injury Cost and Resulting Benefit for Akiak-Akiachak ATV Trail

\begin{tabular}{|c|c|c|c|c|c|c|c|c|}
\hline \multirow{3}{*}{ Y ear } & \multirow{3}{*}{$\begin{array}{l}\text { Discount } \\
\text { Factor }\end{array}$} & \multicolumn{7}{|c|}{ A kiak A kiachak } \\
\hline & & & \multicolumn{2}{|c|}{ Without Trail } & \multicolumn{2}{|c|}{ W ith Trail } & \multicolumn{2}{|c|}{ Benefit } \\
\hline & & Population & $\begin{array}{c}\text { Fatality } \\
\text { Value }\end{array}$ & $\begin{array}{l}\text { Injury } \\
\text { Value }\end{array}$ & $\begin{array}{l}\text { Fatality } \\
\text { Value }\end{array}$ & $\begin{array}{l}\text { Injury } \\
\text { Value }\end{array}$ & $\begin{array}{l}\text { Fatality } \\
\text { V alue }\end{array}$ & $\begin{array}{l}\text { Injury } \\
\text { Value }\end{array}$ \\
\hline 2005 & 0.93 & 999 & $\$ 572,981$ & $\$ 159,435$ & 286,490 & $\$ 79,718$ & $\$ 286,490$ & $\$ 79,718$ \\
\hline 2006 & 0.87 & 1,015 & $\$ 543,563$ & $\$ 151,250$ & 271,782 & 75,625 & $\$ 271,782$ & 5,625 \\
\hline 2007 & .82 & 030 & $\$ 515,656$ & $\$ 143,484$ & 257,828 & 11,742 & $\$ 257,828$ & 1,742 \\
\hline 2008 & 76 & 345 & $\$ 489,181$ & $\$ 136,118$ & 244,591 & 68,059 & $\$ 244,591$ & 68,059 \\
\hline 2009 & 0.71 & 1,061 & $\$ 464,066$ & $\$ 129,129$ & 232,033 & $\$ 64,565$ & $\$ 232,033$ & $\$ 64,565$ \\
\hline 2010 & 0.67 & 1,077 & $\$ 440,240$ & $\$ 122,499$ & 220,120 & $\$ 61,250$ & $\$ 220,120$ & $\$ 61,250$ \\
\hline 2011 & 0.62 & 1,093 & $\$ 417,637$ & $\$ 116,210$ & 208,819 & $\$ 58,105$ & $\$ 208,819$ & $\$ 58,105$ \\
\hline 2012 & 0.58 & 110 & $\$ 396,195$ & $\$ 110,244$ & 198,098 & $\$ 55,122$ & $\$ 198,098$ & $\$ 55,122$ \\
\hline 2013 & 54 & 126 & $\$ 375,854$ & $\$ 104,584$ & 187,927 & $\$ 52,292$ & $\$ 187,927$ & $\$ 52,292$ \\
\hline 2014 & 51 & 1,143 & $\$ 356,557$ & $\$ 99,214$ & 178,278 & $\$ 49,607$ & $\$ 178,278$ & $\$ 49,607$ \\
\hline 2015 & 0.48 & 1,161 & $\$ 338,251$ & $\$ 94,120$ & 169,125 & $\$ 47,060$ & $\$ 169,125$ & $\$ 47,060$ \\
\hline 2016 & 0.44 & 1,178 & $\$ 320,884$ & $\$ 89,288$ & 160,442 & $\$ 44,644$ & $\$ 160,442$ & $\$ 44,644$ \\
\hline 2017 & 0.41 & 1,196 & $\$ 304,410$ & $\$ 84,704$ & 152,205 & $\$ 42,352$ & $\$ 152,205$ & $\$ 42,352$ \\
\hline 2018 & 33 & 214 & $\$ 288,781$ & $\$ 80,355$ & 144,390 & $\$ 40,178$ & $\$ 144,390$ & $\$ 40,178$ \\
\hline 2019 & 36 & 232 & $\$ 273,954$ & $\$ 76,229$ & 136,977 & $\$ 38,115$ & $\$ 136,977$ & $\$ 38,115$ \\
\hline 2020 & .34 & 1,251 & $\$ 259,889$ & $\$ 72,316$ & 129,945 & $\$ 36,158$ & $\$ 129,945$ & $\$ 36,158$ \\
\hline 2021 & 32 & 1,270 & $\$ 246,546$ & $\$ 68,603$ & 123,273 & $\$ 34,301$ & $\$ 123,273$ & $\$ 34,301$ \\
\hline 2022 & & & $\$ 233,888$ & $\$ 65,081$ & 116,944 & $\$ 32,540$ & $\$ 116,944$ & $\$ 32,540$ \\
\hline 2023 & & & $\$ 221,880$ & $\$ 61,739$ & 110,940 & $\$ 30,870$ & $\$ 110,940$ & $\$ 30,870$ \\
\hline 2024 & 0.26 & 1,328 & $\$ 210,488$ & $\$ 58,570$ & 105,244 & $\$ 29,285$ & $\$ 105,244$ & $\$ 29,285$ \\
\hline resent V alu & & & $\$ 7,270,902$ & $\$ 2,023,172$ & $\$ 3,635,451$ & $\$ 1,011,586$ & $\$ 3,635,451$ & $\$ 1,011,586$ \\
\hline
\end{tabular}

* Population increases are estimated using the population growth (1.5\%) determined from the B ethel Census A rea over the 19912003 period.

\section{Traffic Rates and Forecasts}

Both the benefits and costs of transportation alternatives are dependent upon the traffic volume. Most transportation B-C analyses have the benefit of examining traffic on similar pre-existing roads or the roads being evaluated (Boardman et al. 1994). Because of the lack of preexisting data and the high cost associated with primary data collection, the traffic counts for the proposed transportation corridor had to rely in part on RRA and on assumptions about road alternative effects used in the previously published literature (Boardman et al. 1994 and Walter and Meyers 1987). These travel rates were used as the baseline in assessing traffic rates and fuel costs.

\section{Fuel Savings Benefit Calculations}

Estimated fuel consumption rates by travel mode and travel patterns were used to gauge fuel costs. Travel between the two sets of villages is likely to increase with improvements in the safety, convenience, ease of travel, and with decreases in the cost of travel. Waters and Meyers (1987) estimate that the construction of a new transportation corridor would cause $50 \%$ of traffic on alternative routes to be diverted to the new corridor. Lacking better information, this $50 \%$ switch was adopted as indicative of the expected rate of change between river travel and the proposed alternative ATV trail route. However, this assumption cannot be applied to snow machine travel, because it occurs in the winter months when the ATV corridor would not serve as a substitute for boat travel. Travel will be forecast to increase at the rate of population growth only, lacking specific information to adjust the forecast according to other endogenous factors. Table 5 below outlines traffic rate forecast as well as the method of determining the traffic rates for each mode of transportation in the analysis. The determined traffic rate estimates in the current research are similar to the $10-20$ vehicles daily estimates 
as determined in previous research of the area (State of Alaska Department of Transportation 1981).

Total fuel consumption costs include ATV, boat and snow machine travel. However, variation between the status quo and the alternative will come only from shifts from boat travel to ATV in the warm months. As provided in Table 6, the fuel consumption rates for each method of travel were determined through a combination of RRA and the application of previous research (Davis et al. 1999).

Table 5: Daily Traffic Projections for Alternative Methods of Travel

\begin{tabular}{|c|c|c|c|c|c|c|c|c|c|c|c|c|c|}
\hline \multirow{4}{*}{$\begin{array}{l}\text { Step 1: Determine current } \\
\text { transporatation rates w/o trail } \\
\text { construction through phone } \\
\text { interviews and questionnaires }\end{array}$} & \multirow[b]{3}{*}{ Year } & \multicolumn{6}{|c|}{ Without Trail Construction (round trips) } & \multicolumn{6}{|c|}{ With Trail Construction (round trips) } \\
\hline & & \multicolumn{3}{|c|}{ O scarville-N apakiak } & \multicolumn{3}{|c|}{ A kiak-A kiachak } & \multicolumn{3}{|c|}{ Oscarville-N apakiak } & \multicolumn{3}{|c|}{ A kiak-A kiachak } \\
\hline & & Boat & ATV & SM & Boat & ATV & SM & B oat & ATV & SM & Boat & ATV & SM \\
\hline & $\Rightarrow 2005$ & 2.00 & 1.50 & 5.50 & 13.25 & 25.50 & 25.50 & 1.00 & 2.50 & 5.50 & & & 2556 \\
\hline \multirow{4}{*}{$\begin{array}{l}\text { Step 2: A pply population growth } \\
\text { rate of } 1.5 \% \text { to the subsequent } \\
\text { year of analysis. (i.e. } 2 \times .015+2 \\
2.03 \text { ) }\end{array}$} & $\Rightarrow 2006$ & 2.03 & 1.52 & & & & & & 2.54 & & & & \\
\hline & 2007 & 2.06 & 1.55 & & 13.65 & & & & 250 & & & & \\
\hline & 2008 & 2.09 & 1.57 & & 13.86 & & 26. & & 2.61 & & & & \\
\hline & 2009 & 2.12 & 1.59 & 5.84 & 14.0 & & 27. & & & & & & \\
\hline \multirow{8}{*}{ 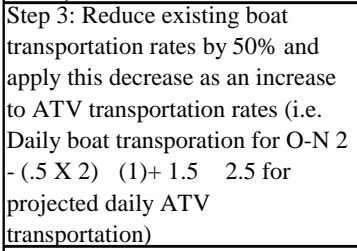 } & 2010 & 2.15 & 1.62 & 5.93 & 14.27 & & 27.47 & & 2.69 & & & & \\
\hline & 2011 & 2.19 & 1.64 & 6.01 & 1449 & & & 1.0 & 2.73 & & & & \\
\hline & 2012 & 2.22 & 1.66 & 6.10 & 14.71 & & 28.30 & & 2.77 & & & & \\
\hline & 2013 & 2.25 & 1.6 & 6.20 & 14.93 & & 28.73 & 1.1 & 2.8 & & & & \\
\hline & 2014 & 2.29 & 1.7 & 6.29 & 15.15 & & 29.16 & 1.1 & 2.86 & & & & \\
\hline & 2015 & 2.32 & 1.7 & 6.38 & 15.38 & & 29. & 1.1 & 2.90 & & & & \\
\hline & 2016 & 2.36 & 1.77 & 6.48 & 15.61 & 30. & 30.04 & 1.1 & 2.94 & & & & 30.0 \\
\hline & 2017 & 2.39 & 1.7 & 6.58 & 15.84 & & 30. & & 2.99 & & & & 30.49 \\
\hline \multirow{7}{*}{$\begin{array}{l}\text { Snow machine traffic rates remain } \\
\text { constant regardless if there is a trail } \\
\text { developed or not. This is because } \\
\text { winter time travel will be restricted } \\
\text { to snow machines only. }\end{array}$} & 2018 & 2.43 & 1.8 & 6.67 & 16.08 & 30. & 30.95 & & 3.03 & & & & 30.95 \\
\hline & 2019 & 2.46 & 1.85 & 6.77 & 16.32 & 31. & 31.41 & & 3.08 & & & & 31.4 \\
\hline & 2020 & 2.50 & 1.88 & 6.88 & 16.57 & 31. & 31.88 & 1.25 & 3.13 & & & & 31.88 \\
\hline & 2021 & 2.54 & 1.90 & 6.98 & 16.81 & 32.36 & 32.36 & 1.27 & 3.17 & & & & 32.3 \\
\hline & 2022 & 2.58 & 1.93 & 7.08 & 17.07 & 32. & 32.84 & 1.29 & 3.22 & 7. & & & 32.8 \\
\hline & 2023 & 2.61 & 1.96 & 7.19 & 17.32 & 33. & 33.34 & 1.31 & 3.27 & & & & 33.3 \\
\hline & & 2.65 & 1.99 & 7.30 & 17.58 & 33.84 & 33.84 & 1.33 & 3.32 & 7.30 & 8.79 & 42.63 & 33.8 \\
\hline
\end{tabular}

Table 6: Fuel Cost for Separate Travel Methods

\begin{tabular}{|c|c|c|c|}
\hline \multicolumn{4}{|l|}{ Oscarville- Napakiak } \\
\hline & Boat & ATV & Snowmachine \\
\hline M iles/per gallon* & 5 & 55 & 15 \\
\hline M iles round trip & 14 & 23 & 23 \\
\hline Fuel Cost per gallon & $\$ 3.65$ & $\$ 3.65$ & $\$ 3.65$ \\
\hline Gallons/round trip & 2.75 & 0.42 & 1.53 \\
\hline $\begin{array}{l}\text { Fuel expenditure per } \\
\text { trip }\end{array}$ & $\$ 10.04$ & $\$ 1.53$ & $\$ 5.60$ \\
\hline Cost per mile & $\$ 0.72$ & $\$ 0.07$ & $\$ 0.24$ \\
\hline \multicolumn{4}{|l|}{ Akiak-Akiachak } \\
\hline & Boat & ATV & Snowmachine \\
\hline M iles/per gallon* & 5 & 55 & 15 \\
\hline M iles round trip & 25 & 16 & 16 \\
\hline Fuel cost per gallon & $\$ 3.45$ & $\$ 3.45$ & $\$ 3.45$ \\
\hline Gallons/round trip & 5 & 0.29 & 1.07 \\
\hline $\begin{array}{l}\text { Fuel expenditure per } \\
\text { trip }\end{array}$ & $\$ 17.25$ & $\$ 1.00$ & $\$ 3.68$ \\
\hline Cost per mile & $\$ 0.69$ & $\$ 0.06$ & $\$ 0.23$ \\
\hline
\end{tabular}

*ATV and snow machine mpg estimates were determined by using the average per hour consumption as determined by Davis et al. (1999). Boat mpg estimates for both communities were developed using OscarvilleNapakiak estimates. 
The benefits of boat fuel savings are apparent in Tables 8 and 9. These totals are determined by the methodology outlined in Table 7. The table uses 2005 O-N data to illustrate how the data in the first row of Table 8 was determined. Fuel costs without trail construction are determined first and are provided in the top four rows of Table 7. It was determined that the fuel benefits of ATV trail construction would only come from a shift of the current boat traffic to ATV travel. Therefore, benefits are derived in a 120 day period where ATV travel would serve as a substitute for boat travel. There are approximately four months of the year (120 days) where the Kuskokwim River would prove to be a safe alternative for
ATV travel. Snow machine travel is assumed to last for eight months or approximately 245 days and is not treated as a substitute for either boat or ATV travel in the current analysis. The second column of Table 7 depicts the daily number of round trips for 2005 and was determined from a series of phone interviews and questionnaires. The final row of Table 7 reveals that after total fuel costs are determined for the with and without-trail alternatives they are subtracted from one another and discounted to provide the 2005 present value of net fuel benefit. This value is summed over the years of analysis (2005-2024) and provides the total net present value of fuel benefit in the final rows of both Table 8 and Table 9.

Table 7: Fuel Costs Net Benefit Calculations

\begin{tabular}{|c|c|c|c|c|c|c|c|}
\hline 2005 & $\begin{array}{l}\text { Days of } \\
\text { Usage }\end{array}$ & & $\begin{array}{l}\text { Round } \\
\text { Trips } \\
\text { (per dav) }\end{array}$ & & $\begin{array}{c}\text { Costs per } \\
\text { Round } \\
\text { Trip }\end{array}$ & & $\begin{array}{l}\text { Total Fuel } \\
\text { Costs }\end{array}$ \\
\hline \multicolumn{8}{|l|}{ Without Trail Construction } \\
\hline A nnual B oat Fuel Costs & 120 & $X$ & 2.00 & $\mathrm{X}$ & $\$ 10.04$ & $=$ & $\$ 2,409$ \\
\hline A nnual ATV Fuel Costs & 120 & $X$ & 1.50 & $\mathrm{X}$ & $\$ 1.53$ & $=$ & $\$ 275$ \\
\hline $\begin{array}{l}\text { A nnual Snowmachine Fuel } \\
\text { Costs }\end{array}$ & 245 & $X$ & 5.50 & $X$ & $\$ 5.60$ & $=$ & $\$ 7,542$ \\
\hline Total Fuel Costs & & & & & & & $\$ 10,225$ \\
\hline \multicolumn{8}{|l|}{ With Trail Construction } \\
\hline A nnual B oat Fuel Costs & 120 & $x$ & 1.00 & $\mathrm{X}$ & $\$ 10.04$ & $=$ & $\$ 1,205$ \\
\hline A nnual ATV Fuel Costs & 120 & $x$ & 2.50 & $x$ & $\$ 1.53$ & $=$ & $\$ 458$ \\
\hline $\begin{array}{l}\text { A nnual Snowmachine Fuel } \\
\text { Costs }\end{array}$ & 245 & $X$ & 5.50 & $X$ & $\$ 5.60$ & $=$ & $\$ 7,542$ \\
\hline \multirow[t]{2}{*}{ Total Fuel Costs } & & & & & & & $\$ 9,204$ \\
\hline & $\begin{array}{l}\text { Total Fuel } \\
\text { Costs w/o } \\
\text { A TV Trail }\end{array}$ & & $\begin{array}{l}\text { Total Fuel } \\
\text { Costs with } \\
\text { ATV Trail }\end{array}$ & & $\begin{array}{l}\text { Discount } \\
\text { Factor }\end{array}$ & & $\begin{array}{c}\text { Present } \\
\text { V alue of } \\
\text { Net }\end{array}$ \\
\hline $\begin{array}{l}\text { Net Present V alue of Benefit } \\
\text { Calculations }\end{array}$ & $\$ 10,225$ & & $\$ 9,204$ & $\mathrm{X}$ & 0.93 & $=$ & $\$ 955$ \\
\hline
\end{tabular}

*Computations may be slightly off due to rounding error. 
ATV Transportation Corridor

A-A has a much higher fuel consumption benefit present value than $\mathrm{O}-\mathrm{N}$, with A-A having $\$ 140,993$ more in fuel consumption benefits. This is attributed to the traffic projection estimates for both community subsets. Due to trail construction, daily ATV traffic for O$\mathrm{N}$ is slightly more than three trips per day by 2024, whereas A-A daily ATV traffic increases to approximately 43 trips per day by 2024 . This is logical since Akiak and Akiachak are further removed from the population hub of Bethel than that of Oscarville and Napakiak. Akiak and Akiachak have more dependence on one another for services and goods where as Oscarville and Napakiak rely heavily on Bethel for services and goods. Without trail construction, daily ATV traffic between O-N is approximately two trips and approximately 34 trips for Akaik-Akiachak.

Table 8: Fuel Cost and Resulting Benefits for Oscarville-Napakiak Trail

\begin{tabular}{|c|c|c|c|c|c|c|c|c|c|}
\hline \multirow[b]{2}{*}{ Y ear } & \multicolumn{4}{|c|}{ Without Trail Construction } & \multicolumn{5}{|c|}{ With Trail Construction } \\
\hline & \begin{tabular}{|l|} 
Boat \\
\end{tabular} & ATV & Snowmachine & Total & Boat & ATV & Snowmachine & Total & Benefit \\
\hline 2005 & $\$ 2,409$ & $\$ 275$ & $\$ 7,542$ & $\$ 10,225$ & $\$ 1,205$ & $\$ 458$ & $\$ 7,542$ & $\$ 9,204$ & $\$ 955$ \\
\hline 2006 & $\$ 2,445$ & $\$ 279$ & $\$ 7,655$ & $\$ 10,379$ & $\$ 1,223$ & $\$ 465$ & $\$ 7,655$ & $\$ 9,342$ & $\$ 905$ \\
\hline 2007 & $\$ 2,482$ & $\$ 283$ & $\$ 7,769$ & $\$ 10,534$ & $\$ 1,241$ & $\$ 472$ & $\$ 7,769$ & $\$ 9,482$ & $\$ 859$ \\
\hline 2008 & $\$ 2,519$ & $\$ 287$ & $\$ 7,886$ & $\$ 10,692$ & $\$ 1,260$ & $\$ 479$ & $\$ 7,886$ & $\$ 9,624$ & $\$ 815$ \\
\hline 2009 & $\$ 2,557$ & $\$ 292$ & $\$ 8,004$ & $\$ 10,853$ & $\$ 1,278$ & $\$ 486$ & $\$ 8,004$ & $\$ 9,769$ & $\$ 773$ \\
\hline 2010 & $\$ 2,595$ & $\$ 296$ & $\$ 8,124$ & $\$ 11,016$ & $\$ 1,298$ & $\$ 493$ & $\$ 8,124$ & $\$ 9,915$ & $\$ 733$ \\
\hline 2011 & $\$ 2,634$ & $\$ 300$ & $\$ 8,246$ & $\$ 11,181$ & $\$ 1,317$ & $\$ 501$ & $\$ 8,246$ & $\$ 10,064$ & $\$ 695$ \\
\hline 2012 & $\$ 2,674$ & $\$ 305$ & $\$ 8,370$ & $\$ 11,348$ & $\$ 1,337$ & $\$ 508$ & $\$ 8,370$ & $\$ 10,215$ & $\$ 660$ \\
\hline 2013 & $\$ 2,714$ & $\$ 309$ & $\$ 8,495$ & $\$ 11,519$ & $\$ 1,357$ & $\$ 516$ & $\$ 8,495$ & $\$ 10,368$ & $\$ 626$ \\
\hline 2014 & $\$ 2,754$ & $\$ 314$ & $\$ 8,623$ & $\$ 11,691$ & $\$ 1,377$ & $\$ 524$ & $\$ 8,623$ & $\$ 10,524$ & $\$ 594$ \\
\hline 2015 & $\$ 2,796$ & $\$ 319$ & $\$ 8,752$ & $\$ 11,867$ & $\$ 1,398$ & $\$ 531$ & $\$ 8,752$ & $\$ 10,682$ & $\$ 563$ \\
\hline 2016 & $\$ 2,838$ & $\$ 324$ & $\$ 8,884$ & $\$ 12,045$ & $\$ 1,419$ & $\$ 539$ & $\$ 8,884$ & $\$ 10,842$ & $\$ 534$ \\
\hline 2017 & $\$ 2,880$ & $\$ 328$ & $\$ 9,017$ & $\$ 12,225$ & $\$ 1,440$ & $\$ 547$ & $\$ 9,017$ & $\$ 11,004$ & $\$ 507$ \\
\hline 2018 & $\$ 2,923$ & $\$ 333$ & $\$ 9,152$ & $\$ 12,409$ & $\$ 1,462$ & $\$ 556$ & $\$ 9,152$ & $\$ 11,169$ & $\$ 481$ \\
\hline 2019 & $\$ 2,967$ & $\$ 338$ & $\$ 9,289$ & $\$ 12,595$ & $\$ 1,484$ & $\$ 564$ & $\$ 9,289$ & $\$ 11,337$ & $\$ 456$ \\
\hline 2020 & $\$ 3,012$ & $\$ 343$ & $\$ 9,429$ & $\$ 12,784$ & $\$ 1,506$ & $\$ 572$ & $\$ 9,429$ & $\$ 11,507$ & $\$ 433$ \\
\hline 2021 & $\$ 3,057$ & $\$ 349$ & $\$ 9,570$ & $\$ 12,976$ & $\$ 1,528$ & $\$ 581$ & $\$ 9,570$ & $\$ 11,680$ & $\$ 410$ \\
\hline 2022 & $\$ 3,103$ & $\$ 354$ & $\$ 9,714$ & $\$ 13,170$ & $\$ 1,551$ & $\$ 590$ & $\$ 9,714$ & $\$ 11,855$ & $\$ 389$ \\
\hline 2023 & $\$ 3,149$ & $\$ 359$ & $\$ 9,859$ & $\$ 13,368$ & $\$ 1,575$ & $\$ 599$ & $\$ 9,859$ & $\$ 12,033$ & $\$ 369$ \\
\hline 2024 & $\$ 3,197$ & $\$ 365$ & $\$ 10,007$ & $\$ 13,568$ & $\$ 1,598$ & $\$ 608$ & $\$ 10,007$ & $\$ 12,213$ & $\$ 350$ \\
\hline Present V alue & & & & & & & & & $\$ 12,106$ \\
\hline
\end{tabular}

Table 9: Fuel Cost and Resulting Benefits for Akiak-Akiachak Trail

\begin{tabular}{|c|c|c|c|c|c|c|c|c|c|}
\hline \multirow[b]{2}{*}{ Year } & \multicolumn{4}{|c|}{ Without trail construction } & \multicolumn{5}{|c|}{ With Trail Construction } \\
\hline & \begin{tabular}{|l|} 
Boat \\
\end{tabular} & ATV & Snowmachine & Total & Boat & ATV & Snowmachine & Total & Benefit \\
\hline 2005 & $\$ 27,428$ & $\$ 3,071$ & $\$ 22,991$ & $\$ 53,489$ & $\$ 13,714$ & $\$ 3,869$ & $\$ 22,991$ & $\$ 40,574$ & $\$ 12,071$ \\
\hline 2006 & $\$ 27,839$ & $\$ 3,117$ & $\$ 23,336$ & $\$ 54,292$ & $\$ 13,919$ & $\$ 3,927$ & $\$ 23,336$ & $\$ 41,182$ & $\$ 11,450$ \\
\hline 2007 & $\$ 28,256$ & $\$ 3,164$ & $\$ 23,686$ & $\$ 55,106$ & $\$ 14,128$ & $\$ 3,986$ & $\$ 23,686$ & $\$ 41,800$ & $\$ 10,862$ \\
\hline 2008 & $\$ 28,680$ & $\$ 3,211$ & $\$ 24,041$ & $\$ 55,933$ & $\$ 14,340$ & $\$ 4,046$ & $\$ 24,041$ & $\$ 42,427$ & $\$ 10,304$ \\
\hline 2009 & $\$ 29,111$ & $\$ 3,260$ & $\$ 24,402$ & $\$ 56,772$ & $\$ 14,555$ & $\$ 4,106$ & $\$ 24,402$ & $\$ 43,063$ & $\$ 9,774$ \\
\hline 2010 & $\$ 29,547$ & $\$ 3,308$ & $\$ 24,768$ & $\$ 57,623$ & $\$ 14,774$ & $\$ 4,168$ & $\$ 24,768$ & $\$ 43,709$ & $\$ 9,272$ \\
\hline 2011 & $\$ 29,990$ & $\$ 3,358$ & $\$ 25,139$ & $\$ 58,488$ & $\$ 14,995$ & $\$ 4,231$ & $\$ 25,139$ & $\$ 44,365$ & $\$ 8,795$ \\
\hline 2012 & $\$ 30,440$ & $\$ 3,408$ & $\$ 25,516$ & $\$ 59,365$ & $\$ 15,220$ & $\$ 4,294$ & $\$ 25,516$ & $\$ 45,030$ & $\$ 8,343$ \\
\hline 2013 & $\$ 30,897$ & $\$ 3,460$ & $\$ 25,899$ & $\$ 60,255$ & $\$ 15,448$ & $\$ 4,358$ & $\$ 25,899$ & $\$ 45,706$ & $\$ 7,914$ \\
\hline 2014 & $\$ 31,360$ & $\$ 3,511$ & $\$ 26,287$ & $\$ 61,159$ & $\$ 15,680$ & $\$ 4,424$ & $\$ 26,287$ & $\$ 46,391$ & $\$ 7,507$ \\
\hline 2015 & $\$ 31,831$ & $\$ 3,564$ & $\$ 26,682$ & $\$ 62,077$ & $\$ 15,915$ & $\$ 4,490$ & $\$ 26,682$ & $\$ 47,087$ & $\$ 7,121$ \\
\hline 2016 & $\$ 32,308$ & $\$ 3,618$ & $\$ 27,082$ & $\$ 63,008$ & $\$ 16,154$ & $\$ 4,558$ & $\$ 27,082$ & $\$ 47,794$ & $\$ 6,755$ \\
\hline 2017 & $\$ 32,793$ & $\$ 3,672$ & $\$ 27,488$ & $\$ 63,953$ & $\$ 16,396$ & $\$ 4,626$ & $\$ 27,488$ & $\$ 48,510$ & $\$ 6,408$ \\
\hline 2018 & $\$ 33,285$ & $\$ 3,727$ & $\$ 27,901$ & $\$ 64,912$ & $\$ 16,642$ & $\$ 4,695$ & $\$ 27,901$ & $\$ 49,238$ & $\$ 6,079$ \\
\hline 2019 & $\$ 33,784$ & $\$ 3,783$ & $\$ 28,319$ & $\$ 65,886$ & $\$ 16,892$ & $\$ 4,766$ & $\$ 28,319$ & $\$ 49,977$ & $\$ 5,766$ \\
\hline 2020 & $\$ 34,291$ & $\$ 3,840$ & $\$ 28,744$ & $\$ 66,874$ & $\$ 17,145$ & $\$ 4,837$ & $\$ 28,744$ & $\$ 50,726$ & $\$ 5,470$ \\
\hline 2021 & $\$ 34,805$ & $\$ 3,897$ & $\$ 29,175$ & $\$ 67,877$ & $\$ 17,403$ & $\$ 4,910$ & $\$ 29,175$ & $\$ 51,487$ & $\$ 5,189$ \\
\hline 2022 & $\$ 35,327$ & $\$ 3,956$ & $\$ 29,613$ & $\$ 68,895$ & $\$ 17,664$ & $\$ 4,983$ & $\$ 29,613$ & $\$ 52,260$ & $\$ 4,922$ \\
\hline 2023 & $\$ 35,857$ & $\$ 4,015$ & $\$ 30,057$ & $\$ 69,929$ & $\$ 17,929$ & $\$ 5,058$ & $\$ 30,057$ & $\$ 53,043$ & $\$ 4,669$ \\
\hline 2024 & $\$ 36,395$ & $\$ 4,075$ & $\$ 30,508$ & $\$ 70,978$ & $\$ 18,197$ & $\$ 5,134$ & $\$ 30,508$ & $\$ 53,839$ & $\$ 4,429$ \\
\hline Present V alue & & & & & & & & & $\$ 153,099$ \\
\hline
\end{tabular}




\section{Summary of Benefit Estimates}

The vast majority of ATV trail construction benefits are attributed to safety improvements. A $50 \%$ reduction in current transportation fatalities and injuries creates a combined benefit of $\$ 2,098,490$ for O-N and a benefit of $\$ 4,647,037$ for A-A. In comparison, the benefit of reducing fuel consumption is $\$ 12,106$ for O-N and \$153,099 for the Akaik-Akiachak trail. The total present value of benefits for $\mathrm{O}-\mathrm{N}$ and A-A are $\$ 2,110,596$ and $\$ 4,800,136$, respectively, during the 20-year life of the ATV project.

\section{COST CALCULATION}

\section{Construction}

Construction cost estimates includes materials, shipping, andlaborandaredependentondistance, number of bridges, and variability in terrain. The Bethel to Napakiak Road Reconnaissance Study (BNRRS) was used to estimate the length of the O-N trail as approximately 11.5 miles (State of Alaska Department of Transportation 1981). The length of the Akaik-Akiachak trail will be approximately eight miles, which was determinedbyexamination of aerialphotography and topographical maps of the area. Sales quotes were used for specific material costs and shipping costs. Labor costs were estimated through consultations with a trail development specialist and through methodologies provided by previous research and these procedures are outlined in the research below.

Materials Costs. The anticipated material costs of trail construction include: geotextiles ${ }^{4}$, bridge superstructure, miscellaneous materials, and the fill materials required for bridge construction. These costs are provided in the second column of Table 10. Material costs for trail construction were obtained through a variety of sources. The geotextiles and bridge superstructure costs estimates were collected through consultations with private companies potentially interested in the project. Miscellaneous material costs were estimated through consultations with a trail development specialist, Anchorage-based hardware stores, and, in the instance of screws, from price quotes. The material cost estimates for bridge fill materials were obtained from the BNRRS estimates for a 24-foot-wide bridge designed for car and truck traffic over the same span of the river. The proposed ATV bridge is merely eight feet wide and can support a vehicle load of 10,000 pounds, substantially less than would be needed to support two-way car and truck traffic. In consultation with an engineer, the bridge-crossing material costs for the ATV compatible bridge is estimated to be $45 \%$ of the BNRRS bridge material costs (M. Gurkin, pers. comm.).

The proposed trails are approximately 6.5 feet wide, with the exception of the 8 foot wide bridge crossings, and will be constructed using both Geoblock and SolGrid with a layer of TrailGrid beneath both. This relatively new technology provides serviceable trails that sustain ATV traffic and pose little threat to the environment. The construction of such a road reduces surface runoff, increases infiltration, ${ }^{5}$ resists erosion and enhances ground water recharge when compared to asphalt or concrete pavement (Meyer 2002). The National Park Service (NPS) considered these attributes when faced with the possible closure of the only ATV trail into the Palmer Hay Flats State Game Refuge (Presto Products Company n.d.). Rather than closing the ATV corridor or constructing an expensive traditional trail, NPS constructed a geotextile trail through the wetland, which preserves the wetlands natural vegetation.

Geoblock and SolGrid are used in combination because of the characteristics of both materials. Geoblock expands and contracts because of the extreme temperature variation in Alaska. In some instances 12 inches of variance was observed in the length of a 100 foot section of Geoblock on some existing trails in Alaska (Meyer 2002). Therefore, the construction of a trail 46' x 6.5' of Geoblock connected to 6.5' $\times$ 6.5' of SolGrid in a repeating pattern was determined to be the most practical option. SolGrid allows for the Geoblock to contract or expand since SolGrid has expansion components. Material costs are identical for Option A and B except for that of the bridge material costs (Table 10). The material costs of Geoblock for both trails were estimated from quotes from GeoChem Inc. and SolPlast Inc. The O-N trail, both 
Table 10:Trail Construction Cost

\begin{tabular}{|c|c|c|c|c|}
\hline \multicolumn{5}{|c|}{ Oscarville-Napakiak Option A } \\
\hline \multirow{2}{*}{ Designation } & \multirow{2}{*}{ M aterial } & \multirow{2}{*}{ Labor } & \multicolumn{2}{|c|}{ Shipment } \\
\hline & & & To Seattle & To B ethel \\
\hline M isc. M aterial & $\$ 28,694$ & \multirow{4}{*}{$\$ 97,152$} & $\mathrm{NA}$ & NA \\
\hline Geoblock & $\$ 743,888$ & & $\$ 58,124$ & \multirow{5}{*}{$\$ 522,371$} \\
\hline SolGrid & $\$ 115,051$ & & $\$ 16,209$ & \\
\hline TrailGrid & $\$ 83,835$ & & $\$ 3,700$ & \\
\hline Big R Bridge & $\$ 737,862$ & $\$ 184,465$ & $\mathrm{NA}$ & \\
\hline $\begin{array}{l}\text { E.T. Techtonics } \\
\text { Bridge }\end{array}$ & $\$ 31,875$ & $\$ 7,969$ & $\$ 6,000$ & \\
\hline Sub-Total & $\$ 1,741,205$ & $\$ 289,586$ & $\$ 84,033$ & $\$ 522,371$ \\
\hline \multicolumn{4}{|l|}{ Total Cost } & $\$ 2,637,195$ \\
\hline \multicolumn{5}{|c|}{ Oscarville - Napakiak Option B } \\
\hline \multirow{2}{*}{ Designation } & \multirow{2}{*}{ M aterial } & \multirow{2}{*}{ Labor } & \multicolumn{2}{|c|}{ Shipment } \\
\hline & & & To Seattle & To B ethel \\
\hline M isc. M aterial & $\$ 28,694$ & \multirow{4}{*}{$\$ 97,152$} & $\mathrm{NA}$ & NA \\
\hline Geoblock & $\$ 743,888$ & & $\$ 58,124$ & \multirow{4}{*}{$\$ 441,115$} \\
\hline SolGrid & $\$ 115,051$ & & $\$ 16,209$ & \\
\hline TrailGrid & $\$ 83,835$ & & $\$ 3,700$ & \\
\hline $\begin{array}{l}\text { E.T. Techtonics } \\
\text { B ridge }\end{array}$ & $\$ 31,875$ & $\$ 7,969$ & $\$ 6,000$ & \\
\hline Swalling Bridge & $\$ 562,500$ & $\$ 187,500$ & $\mathrm{NA}$ & $\mathrm{NA}$ \\
\hline Sub-T otal & $\$ 1,565,843$ & $\$ 292,621$ & $\$ 84,033$ & $\$ 441,115$ \\
\hline \multicolumn{4}{|l|}{ Total Cost } & $\$ 2,383,612$ \\
\hline \multicolumn{5}{|l|}{ A kiak - A kiachak } \\
\hline \multirow{2}{*}{ Designation } & \multirow{2}{*}{ M aterial } & \multirow{2}{*}{ Labor } & \multicolumn{2}{|c|}{ Shipment } \\
\hline & & & To Seattle & To B ethel \\
\hline M isc. M aterial & $\$ 24,053$ & \multirow{4}{*}{$\$ 67,584$} & $\mathrm{NA}$ & NA \\
\hline Geoblock & $\$ 517,414$ & & $\$ 40,428$ & \multirow{4}{*}{$\$ 315,173$} \\
\hline SolGrid & $\$ 87,408$ & & $\$ 11,276$ & \\
\hline TrailGrid & $\$ 58,374$ & & $\$ 3,700$ & \\
\hline $\begin{array}{l}\text { E.T. Techtonics } \\
\text { Bridge }\end{array}$ & $\$ 31,875$ & $\$ 7,969$ & $\$ 6,000$ & \\
\hline Sub-T otal & $\$ 719,124$ & $\$ 75,553$ & $\$ 61,404$ & $\$ 315,173$ \\
\hline \multicolumn{4}{|l|}{ Total Cost } & $\$ 1,171,254$ \\
\hline
\end{tabular}

Labor cost for bridges are equivalent to $25 \%$ of the bridge material cost 
Option A and B, will require 334,570 square feet $\left(\mathrm{ft}^{2}\right)$ of Geoblock, 55,940 $\mathrm{ft}^{2}$ of SolGrid, and $364,320 \mathrm{ft}^{2}$ of TrailGrid; this comes to $\$ 743,888, \$ 115,051$, and $\$ 83,835$, respectively for a total geotextile cost of $\$ 942,774$. A-A will require 232,745 $\mathrm{ft}^{2}$ of Geoblock, 38,915 $\mathrm{ft}^{2}$ of SolGrid, and $253,440 \mathrm{ft}^{2}$ of TrailGrid. The A-A trail material costs are $\$ 517,414$ for Geoblock, $\$ 87,408$ for SolGrid, and \$58,374 for TrailGrid, or $\$ 663,196$ in total.

Bridge Material. The $\mathrm{O}-\mathrm{N}$ trail will require the construction of two bridges, while A-A will require one. Bridge material costs include the bridge-superstructure and fill-material costs. Bridge-superstructure costs were established from sales quotes from prefabricated bridge manufactures and construction firms. Fill material costs were determined by a combination of examining cost estimates from previous research and from sale quotes (M. Gurkin, pers. comm.).

\section{Oscarville-Napakiak Bridge Alternatives}

The O-N trail will require two separate river crossings, with one being 300 feet and the other being 75 feet. The 300 foot bridge crossing for the $\mathrm{O}-\mathrm{N}$ trail is evaluated by examining two separate alternatives. Option A evaluates the use of a prefabricated bridge produced by Big $\mathrm{R}$ bridges. Option B assesses a bridge constructed by Swalling Construction, an Anchorage based construction firm (Table 10).

Option A superstructure costs were ascertained from a sales quote from Big $\mathrm{R}$ bridge manufactures (R. Warner, pers. comm.). This sale quote does not include fill material costs estimates. Fill material costs were obtained from the BNRRS for the Napakiak Slough crossing and adjusted to 2003 dollars.

Option B bridge costs were similarly ascertained from a sales quote (M. Swalling, pers. comm.). This sale quote included the costs for the total bridge construction project, inclusive of fill material cost.

Regardless of which 300 foot bridge alternative is selected, an additional bridge of 75 feet will be necessary for the $\mathrm{O}-\mathrm{N}$ trail. The 75 foot crossing costs were obtained from E.T. Techtonics, a prefabricated bridge manufacture
(E. Johansson, pers. comm.). Fill material costs for the 75 foot crossing are assumed to be trivial and are, therefore, omitted from the cost estimates.

Option A bridge material cost is $\$ 737,862$ while Option B is $\$ 562,500$. This difference is due to required piling for Option $A$, whereas Option B has no such requirement. Including the 75 foot bridge crossing, Option A bridge material costs account for $28 \%$ of the total construction cost of the O-N trail, while Option B bridge material costs account for $24 \%$ of the total trail construction costs.

\section{Akiak-Akiachak Bridge}

The A-A trail requires the construction of a 75 foot bridge. The sales quote as provided by E.T. Techtonics was used for the bridge cost estimate. Similarly, the fill material costs for the A-A trail are considered inconsequential and have been omitted from the current calculations. The bridge construction cost of $\$ 31,875$ for the A-A trail accounts for $3 \%$ of the total trail construction costs.

Miscellaneous Material Cost. Miscellaneous material costs are the estimated costs associated with the trail construction. These costs were estimated from a combination of sources including Anchorage-based hardware stores, Meyer (2002), and consultations with a trail development specialist (K. Meyer, pers. comm.). Screws are the major component of miscellaneous material costs. The trail requires eighteen \#8 3/4 inch stainless steel screws per linear foot. Because the trail from Oscarville to Napakiak is 60,720 feet, approximately 1.1 million screws are needed. The total cost of screws for the entire O-N trail is $\$ 13,771$ and comprises $48 \%$ of the total miscellaneous materials cost. Similarly, the A-A trail requires 760,320 screws, equating to $\$ 9,580$, which comprises $40 \%$ of the total miscellaneous materials cost for trail construction.

\section{Shipping Costs}

Alternatives for transporting the materials are severely limited because of the lack of both roads and rail lines in the area. Therefore, 
shipping can only be accommodated through waterway routes or small plane travel. Shipping costs from each material source was determined by each of the material providers to Seattle with the exception of miscellaneous cost. Shipping costs from Seattle to Bethel was determined by consultation with a Carlile Transportation Systems shipping line and these estimates are shown in the fifth column of Table 10 (B. Peterson, pers. comm.).

\section{Labor Costs}

The labor costs of the trails are divided into bridge construction and trail construction. B$\mathrm{C}$ analyses typically assign the wage rate or less as the opportunity cost of labor employed in construction. Because the regional labor market is extremely slack, it is likely that the local opportunity cost of labor potentially employed by this project approaches zero; it is likely that the project would provide work to the currently unemployed or underemployed. Trail construction labor and bridge construction labor costs have been computed separately because of the difference between workers employed to accomplish each task. Trail construction can be a source of employment for local people. Because of the high jobless rate in the villages, the wage rate was adjusted downward by $50 \%$ to reflect the opportunity cost of trail construction labor relative to bridge construction labor. Bridge construction will require the use of heavy machinery and knowledge of soil characteristics to construct a safe crossing. Therefore, bridge construction will have to be outsourced. Outsourced labor is charged at its full rate as a cost of the project.

Including site preparation costs, Geoblock installation costs $\$ 320$ for a trail 100 feet $x 6.42$ feet (K. Meyer, pers. comm.). This cost applied to the length of the 11.5-mile trail for O-N totals $\$ 194,304$ in trail construction labor costs (Table 10). Consultation with a trail design specialist reveals that a crew of five people can complete 200-300 feet of Geoblock trail per day (K. Meyer, pers. comm.). It, therefore, can be expected that the construction will employ 15 workers for the summer. Similarly, the eight- mile A-A trail has a labor cost of $\$ 135,168$ and will employ approximately 10 people.

Bridge construction will require the use of contractors, engineers and soil specialists. It is assumed that skilled labor from outside of the area will be necessary to complete the crossings. Construction costs figures for the 300 foot bridge and the 75 foot bridge were ascertained by using the same methodology used in the BNRRS where $25 \%$ of the bridge material costs were used as the labor charge. Site preparation costs for bridge construction are assumed to be included in this labor charge (M. Swalling, pers. comm.). A field visit by an engineer could give a closer approximation of site preparation costs. However, it was assumed that this cost is included in the bridge labor charge. Bridge labor costs are approximately equivalent for Options A \& B, while the A-A trail has an approximate cost of $\$ 8,000$ (Table 10).

\section{Summary of Costs}

The lowest cost is for the Akaik-Akiachak trail, totaling $\$ 1.2$ million, followed by Option B with a total cost of \$2.4 million, and the most expensive alternative is Option A with \$2.6 million in expenses. Material costs account for more than $60 \%$ of the total construction costs for each option and village subset. The second major component of each village subset's costs is shipping costs, accounting for $22-32 \%$ of the total construction costs. The smallest proportion of costs is attributed to that of labor costs, which are between $7-12 \%$ for each village subset.

\section{PROJECT FEASIBILITY}

The net present value (NPV) along with the benefit cost ratio (BCR) and internal rate of return (IRR) for the base analysis were calculated and are provided in Table 11. Under our current analytical assumptions (e.g., 7\% discount rate, 20-year project, zero scrap value, conservative value of life, $50 \%$ reduction in injuries and mortalities), only the A-A trail passes the positive net present value test for project feasibility (Table 11). 
Table 11: Comparison of ATV Trail Alternatives

\begin{tabular}{|c|c|c|c|}
\hline & \multicolumn{2}{|c|}{ Oscarville-N apakiak } & \multirow{2}{*}{$\begin{array}{c}\text { A kiak- } \\
\text { A kiachak }\end{array}$} \\
\hline & \begin{tabular}{|l|} 
Option A \\
\end{tabular} & Option B & \\
\hline \multicolumn{4}{|l|}{ Project Benefits } \\
\hline Fatality B enefit & $\$ 1,794,094$ & $\$ 1,794,094$ & $\$ 3,635,451$ \\
\hline Injury Benefit & $\$ 304,396$ & $\$ 304,396$ & $\$ 1,011,586$ \\
\hline Fuel Consumption B enefit & $\$ 12,106$ & $\$ 12,106$ & $\$ 153,099$ \\
\hline Total B enefit & $\$ 2,110,596$ & $\$ 2,110,596$ & $\$ 4,800,136$ \\
\hline \multicolumn{4}{|l|}{ Project Costs } \\
\hline M aterial & $\$ 1,741,205$ & $\$ 1,565,843$ & $\$ 719,124$ \\
\hline Labor & $\$ 289,586$ & $\$ 292,621$ & $\$ 75,553$ \\
\hline Shipment & $\$ 606,404$ & $\$ 525,147$ & $\$ 376,577$ \\
\hline Total Costs & $\$ 2,637,195$ & $\$ 2,383,612$ & $\$ 1,171,254$ \\
\hline Net Benefits & $-\$ 526,599$ & $-\$ 273,015$ & $\$ 3,628,882$ \\
\hline $\mathrm{BCR}$ & -0.80 & -0.89 & 4.10 \\
\hline IRR & $4.43 \%$ & $5.56 \%$ & $35.96 \%$ \\
\hline
\end{tabular}

Both options for the O-N trail reveal a higher cost than measured benefit. The total net benefits for A-A are \$3.6 million, while Options A and B yield losses of about $\$ 527,000$ and $\$ 273,000$, respectively. As a result, the BCR is negative for both Options $\mathrm{A}$ and $\mathrm{B}$ and reaches 4.10 for the A-A alternative. IRR calculations reveal that Options A and B are robust only to discount rates of $4.4 \%$ and $5.6 \%$, respectively, while the A-A route indicates a far higher expected return of $35.96 \%$.

\section{SENSITIVITY ANALYSIS}

Sensitivity analysis is typically undertaken to assess the stability of the B-C estimates to feasible variation in the important model variables. In this case, project duration and value of life provided the likely important sources of variation, and therefore were subjected to sensitivity analysis. First, the project was evaluated based upon a 15, 25, and 30-year time horizon in addition to the original 20-year project lifetime. Secondly, the implications of higher published values of human life are explored on the justification that lost wages do not reflect the value of a human life to society, only the value of their professional life.

\section{Project Life Adjustment}

The base model's 20-year life evaluation was changed to reflect multiple project lives, including 15 years, 25 years, and 30 years (Table 12). The results for Option A and the A-A route are robust to changes in project life; policy recommendations regarding these two options do not change with project length. Moreover, the A-A route is highly robust to changes in project life, indicating less than $0.5 \%$ difference in annual expected return by doubling the length of the project. However, Option B meets the feasibility criteria when project life extends to 30 years, but not for 25 years or less. As transportation infrastructure planning could potentially extend to 30 years, this may be an important finding with regard to Option B.

\section{Statistical Life Value}

The value of a statistical life in the base analysis is \$2.7 million (Boardman et al. 2001). The sensitivity analysis changed the value of life to Boardman et al. (2001) upper bound estimate of $\$ 4.38$ million, though even more recent highend estimates can exceed \$6-\$7 million (Viscusi 
Table 12: Project Life Adjustments

\begin{tabular}{|c|c|c|c|}
\hline & \multicolumn{2}{|c|}{ Oscarville-Napakiak } & \multirow{2}{*}{$\begin{array}{l}\text { Akiak- } \\
\text { Akiachak }\end{array}$} \\
\hline & \begin{tabular}{|l|} 
Option A \\
\end{tabular} & Option B & \\
\hline \multicolumn{4}{|c|}{ Net Benefit } \\
\hline 15-Y ear & $-\$ 867,007$ & $-\$ 613,423$ & $\$ 2,854,704$ \\
\hline 20-Y ear & $-\$ 526,599$ & $-\$ 273,015$ & $\$ 3,628,882$ \\
\hline 25-Y ear & $-\$ 265,053$ & $-\$ 11,470$ & $\$ 4,223,703$ \\
\hline 30-Y ear & $-\$ 64,100$ & $\$ 189,484$ & $\$ 4,680,718$ \\
\hline \multicolumn{4}{|l|}{$\mathrm{BCR}$} \\
\hline 15-Y ear & -0.67 & -0.74 & 3.44 \\
\hline 20-Y ear & -0.80 & -0.89 & 4.10 \\
\hline 25-Y ear & -0.90 & -1.00 & 4.61 \\
\hline 30-Y ear & -0.98 & 1.08 & 5.00 \\
\hline \multicolumn{4}{|l|}{ IRR } \\
\hline 15-Y ear & $1.47 \%$ & $2.78 \%$ & $35.62 \%$ \\
\hline 20-Y ear & $4.43 \%$ & $5.56 \%$ & $35.96 \%$ \\
\hline 25-Y ear & $5.93 \%$ & $6.95 \%$ & $36.04 \%$ \\
\hline 30-Y ear & $6.78 \%$ & $7.71 \%$ & $36.06 \%$ \\
\hline
\end{tabular}

and Aldy 2003). Under these conditions, all project options become economically feasible, but their relative ranks do not change, as all were equally risk-reducing in our calculations. Locally low wages, high unemployment and short life spans tend to reduce the appropriate value-of-life estimate in this case from a human capital perspective. However, high rates of participation in nonmarket and quasi-market activities (e.g., hunting, fishing), in relatively small and tight-knit communities increase the appropriate value of each life from a socialcapital perspective. Depending on the analytical perspective and the objectives of the policy, it could be reasonable to argue for high or low statistical values of life in this case.

Table 13: Statistical Life Value Adjustment

\begin{tabular}{|c|c|c|c|}
\hline & \multicolumn{2}{|c|}{ Oscarville-N apakiak } & \multirow{2}{*}{$\begin{array}{c}\text { A kiak- } \\
\text { A kiachak } \\
\end{array}$} \\
\hline & Option A & Option B & \\
\hline \multicolumn{4}{|l|}{ Project Benefits } \\
\hline Fatality B enefit & $\$ 2,870,551$ & $\$ 2,870,551$ & $\$ 5,816,721$ \\
\hline Injury Benefit & $\$ 304,396$ & $\$ 304,396$ & $\$ 1,011,586$ \\
\hline Fuel Consumption B enefit & $\$ 12,106$ & $\$ 12,106$ & $\$ 153,099$ \\
\hline Total B enefit & $\$ 3,187,053$ & $\$ 3,187,053$ & $\$ 6,981,407$ \\
\hline \multicolumn{4}{|l|}{ Project Costs } \\
\hline M aterial & $\$ 1,741,205$ & $\$ 1,565,843$ & $\$ 719,124$ \\
\hline Labor & $\$ 289,586$ & $\$ 292,621$ & $\$ 75,553$ \\
\hline Shipment & $\$ 606,404$ & $\$ 525,147$ & $\$ 376,577$ \\
\hline Total Costs & $\$ 2,637,195$ & $\$ 2,383,612$ & $\$ 1,171,254$ \\
\hline Net Benefits & $\$ 549,857$ & $\$ 803,441$ & $\$ 5,810,153$ \\
\hline $\mathrm{BCR}$ & 1.21 & 1.34 & 5.96 \\
\hline IRR & $9.43 \%$ & $10.84 \%$ & $51.75 \%$ \\
\hline
\end{tabular}




\section{Summary of Sensitivity Analysis}

Our calculations are generally robust to changes in project life and variation in the statistical value of a life. In all cases the relative attractiveness of each option remains the same, but the magnitudes of the net benefit calculations vary. A long project life pushes Option B into economically feasible ranges, while the other two alternatives do not change importantly. Changing the value of life simply inflates the benefits proportionately, and pushes all options into the feasible range.

\section{CONCLUSIONS AND LIMITATIONS}

Evaluation of the trail construction alternatives reveals that Akaik-Akiachak trail would be the best alternative for trail construction dollars relative to the other alternatives. O-N ATV trail options provide no net benefit under the base analysis. Sensitivity analysis results further strengthen findings for Akaik-Akiachak and O$\mathrm{N}$ Option A. Some doubts as to the benefits from O-N Option B exist as a result of sensitivity analysis. If the life of the ATV trail were to extend for 30 years, then positive net benefits would be realized.

Limitations in the research include the methodology used in ascertaining traffic projections, the number of fatalities/injuries for travel between the villages, and the exclusion of particular costs. Traffic-rate estimates could be improved by field visits and first-hand evaluation during different seasons of the year. Fatality and injury rates were compiled by evaluating deaths in the area over the specified time period. It should be noted that these deaths might have been for trips to other villages or as the result of recreation where no specific destination was ever assumed.

In addition, engineering costs, geotextile quantity alternatives, maintenance costs, subsistence values, time in transit, and existence values have all been excluded from this evaluation. A precise estimate of engineering costs was financially infeasible for this analysis. This could add a significant amount of costs for sitepreparation in relation to bridge construction. The analysis assumed that the entire length of the trail would be covered with geotextiles. In reality a visit to the site would provide a closer approximation of necessary geotextile material. Maintenance costs have been excluded as the result of consultation with the trail specialist, which stipulated that maintaining the trail would require only four-five days of work for two people. Time in transit costs were not equated because the opportunity costs of labor are low due to high levels of unemployment and the expected time-savings benefit would be low. Existence values for wildlife have been omitted as the result of discussions with a Yukon Delta National Wildlife Refuge (YDNWR) biologist, which determined that the effects of subsistence hunting would be inconsequential.

Moreover, the future may depart from our assumptions about it. Specifically, how economic activity will react to the development of an ATV trail. There may be more transportation to Napakiak from Oscarville for goods and services that are not available locally. The effect that this might have has not been included in the current analysis.

\section{Endnotes}

1. For purposes of this research, ATV's are small, open-motor vehicles having one seat and three or more wheels fitted with large tires. They are designed chiefly for use over roadless, rugged terrain and weigh less than 1,000 pounds.

2. From the human-capital perspective, the opportunity cost of labor is close to zero. However there is a high level of non-market activity in this area that simply cannot be ignored. From the socialcapital perspective these communities' subsistence activities support the food supply with eggs and birds in the spring, salmon in the summer, and caribou in the winter. 
3. The discount factors as presented in Tables 3 and 4 are calculated using the following formula.

Discount Factor $=\frac{1}{(1+\mathrm{r})^{1,2} \mathrm{t}}$

where,

$\mathrm{r}=$ discount rate

$\mathrm{t}=$ discount period

4. Geotextiles are a soil-stabilization apparatus constructed using man-made materials. They are usually made of plastic, rubber, or some similar material.

5. It allows water to penetrate and pass to the ground surface due to the cellular structure of the material.

\section{References}

Alaska Department of Commerce Community and Economic Development. "Community

Database Online.” http://www.commerce.state.ak.us/dca/commdb/CF_BLOCK.htm

Boardman, A., D. Greenberg, A. Vining, and D. Weimer. Cost-Benefit Analysis: Concepts and Practice. $2^{\text {nd }}$ ed. Prentice Hall, Upper Saddle River, NJ, 2001.

Boardman, A., A. Mallery, and A. Vining. "Learning from Ex Ante/Ex Post Cost-Benefit Comparisons: The Coquihalla Highway Example.” Socio-Economic Planning Sciences 28 (2), (1994): 69-84.

Chambers, R. "Rapid Rural Appraisal: Rationale and Repertoire.” Public Administration \& Development 1, (1981): 95-106.

Davis, S., Truett, L. F., and P. S. Hu. "Fuel Used for Off-Road Recreation: A Reassessment of the Fuel Use Model.” Oak Ridge National Laboratory, 1999. http:/www-cta.ornl.gov/cta/Publications/ OffRoad.pdf (accessed November 12, 2004)

Meyer, K. U.S. Forest Service. Managing Degraded Off-Highway Vehicle Trails in Wet, Unstable and Sensitive Environments. Tech Rep. 0223-2821-MTDC. Missoula, MT, 2002.

Miller, T. “The Plausible Range for the Value of Life.” Journal of Forensic Economics 3 (3), (1990): 17-39.

Office of Management and Budget. "Guidelines and Discount Rates for Benefit-Cost Analysis of Federal Programs.” Circulation No. A-94, 1992. http://www.whitehouse.gov/omb/circulars/a094/ a094.html

Olsen, D.O. “A Benefit-Cost Analysis of Improving Alaska's Dalton Highway.” Logistics and Transportation Review 22 (2), (1986): 141-157.

Pacquette, R. J. and P. H. Wright. Highway Engineering. Wiley \& Sons, New York, 1979. 
Presto Products Company. "Alaska Department of Fish and Game Employs Geoblock Trail Hardening System for Degraded Trails Palmer Hay Flats State Game Refuge, Alaska.”

http://www.alcoa.com/alcoa_consumer_products/prestogeo/catalog/pdfs/Palmer_Hay_Flats.pdf

State of Alaska Department of Transportation. Bethel to Napakiak Road Reconnaissance Study. Alaska: Robertson \& Associates, 1981.

U.S. Environmental Protection Agency. "Final Rule for Cleaner Large Industrial Spark Ignition Engines, Recreational Marine Diesel Engines, and Recreational Vehicles.” 2005. http://www.epa. gov/otaq/cleanrec.htm

Viscusi, W. K. and J. E. Aldy. “The Value of a Statistical Life: A Critical Review of Market Estimates throughout the World.” AEI-Brookings Joint Center for Regulatory Studies, 2003. http:// www.aei.brookings.org/admin/authorpdfs/page.php?id=239

Waters II, W.G. and S. J. Meyers. "Benefit-Cost Analysis of a Toll Highway-British Columbia’s Coquihalla.” Journal of the Transportation Research Forum 28 (1), (1987): 435-443.

\section{Acknowledgement}

This project was supported through USDA Cooperative State Research, Education, and Extension Service Award \#2004.06301

Kenneth Lee Elder Jr. (MS 2004, Agricultural and Resource Economics, Colorado State University) is natural resource economist for University of Alaska, Fairbanks Cooperative Extension Service. Research includes community development and resource allocation in areas lacking well-defined cash economies. Prior to working for University of Alaska, Fairbanks, Elder worked as a research assistant for Colorado State University Department of Agricultural and Resource Economics where he explored federal agriculture policy and risk analysis while considering rural community development.

Andrew F. Seidl (Ph.D. 1996, University of Florida) is associate professor \& public policy extension specialist, Department of Agricultural and Resource Economics, Colorado State University. He is also adjunct professor at the Central American Institute for Business Administration (INCAE), Latin American Center for Competitiveness and Sustainable Development (CLACDS) in Costa Rica. Seidl's research involves the community implications of natural resource driven economic development, particularly in areas highly endowed in scenic and recreational natural amenities, open lands preservation, and federal agricultural and resource policy. Prior to joining CSU in 1997, Seidl served as a natural resource economist at the Brazilian Center for Agricultural Research in the Pantanal (CPAP-EMBRAPA), and commodity analyst at the Food and Agriculture Organization of the United Nations (FAO-UN) in Rome, Italy. 